\title{
ŚREDNIOWIECZNA EGZEGEZA KARAIMSKA NA PRZYKŁADZIE WYBRANYCH ZAGADNIEŃ $Z$ KOMENTARZA JEFETA BEN ELIEGO DO KSIĘGI OZEASZA
}

Zachęta Papieskiej Komisji Biblijnej do korzystania z egzegezy żydowskiej zaowocowała wzrostem badań nad wielowiekową żydowską biblijną tradycją interpretacyjną. ${ }^{1}$ Mimo to, po dziś dzień istnieje luka w tych badaniach ze względu na ciągle mało znany obszar biblijnej interpretacji wywodzącej się z żydowskiego środowiska karaimskiego. Brak dostępu do karaimskich materiałów źródłowych na przestrzeni wielu wieków mógł sprawić, że naukowe zainteresowanie karaimską egzegezą zostało mocno ograniczone. Poza tym arabskie środowisko, w którym znaleźli się średniowieczni Karaimi, mogło wywołać niechęć oraz nieco lekceważące podejście do żydowskich dzieł egzegetycznych powstających w kręgach karaimskich osadzonych w środowiskach muzułmańskich. Do tego dochodzi też brak znajomości języka arabskiego oraz judeo-arabskich dialektów używanych przez karaimskich egzegetów, co - z kolei - było powodem zdania się na tłumaczenia z języka arabskiego zwłaszcza na język angielski. ${ }^{2}$

Por. Papieska Komis ja B iblijna, Interpretacja Pisma Świętego w Kościele, tłum. K. R o m a n i u k, Poznań 1994, s. 43-44 (I C 2); t a ż, Naród żydowski i jego święte pisma w Biblii chrześcijańskiej, tłum. R. R u b i n k i e w i c z, Kielce 2002, s. 45-46 (22).

2 Pierwszy znamienny naukowy projekt - który zaowocował wydaniem krytycznym poświęconym dziełom karaimskim - został podjęty na Uniwersytecie Cambridge dopiero w 2000 r. Na ten temat zob. G. K h a n, The Early Karaite Tradition of Hebrew Grammatical Thought. Including a Critical Edition, Translation and Analysis of the Diqduq of 'Abu Ya'qub Yusuf ibn Nuh on the Hagiographa I, w: T. Mur a o k a, C. H. M. Ver st e e g h (red.), Studies in Semitic Languages and Linguistics; t. XXXII, Leiden 2000. Poza tym najobszerniejszy przegląd dzieł badawczych w dziedzinie egzegezy karaimskiej ukazał się w 2011; zob. B. D. W a 1 f i s h, M. K i zil o v, Bibliographia Karaitica. An Annonated Bibliography of 
Niniejsze opracowanie przedstawia wybrane wątki z karaimskiego komentarza do Księgi Ozeasza sporządzonego przez jednego z najwybitniejszych Karaimów średniowiecznych, Jefetego ben Eliego. Poszczególne zagadnienia z tego komentarza omówione tutaj ukazują zasady, którymi kierowali się Karaimi w swoich dziełach komentatorskich. Wynika z nich, że judaizm karaimski łączył egzegezę z zamysłem apologetycznym w celu dotarcia do czytelników muzułmańskich z Biblią Hebrajską.

\section{Judaizm karaimski}

Na temat genezy ruchu karaimskiego są różne teorie, które historycy próbują uwzględnić i połączyć. ${ }^{3}$ Przyjmuje się, że w drugiej połowie VIII w. wśród arabskich Żydów żyjących tam, gdzie islam już był mocno zakorzeniony, toczył się spór między przewodniczącymi szkół rabinackich - geonim - a przewodniczącymi żydowskich gmin w diasporze, określonymi mianem raszej galut. Spór polegał na tym, że geonim reprezentowali żydowską inteligencję czerpiącą swój autorytet przede wszystkim ze znajomości i rozpowszechnienia żydowskiej tradycji ustnej, spisanej w Misznie i Talmudzie. W przeciwieństwie do geonim, raszej galut cieszyli się uznaniem wśród am haarec, czyli prostych Żydów, nieobeznanych z tradycją rabiniczną. W związku z tym niektórzy raszej galut odrzucili tradycję ustną zawartą w Misznie oraz Talmudzie i zażądali od Żydów ścisłego trzymania się tekstów Biblii Hebrajskiej. W ten sposób powstał ruch karaimski, czyli ruch tych, którzy „czytali”, bo słowo karaim wywodzi się ze źródłosłowu kara lub likro - „czytać”, tak że Karaimi stali się osobami postrzegającymi siebie jako prawdziwych ,czytających” i ,słuchających” słowa Bożego - mikra - oraz jemu poddanych

Karaites and Karaism, w: M. P oll i a c k, M. G. W e c h s l e r (red.), Karaite Texts and Studies, t. 2, Leiden 2011.

3 Por. D. J. L a s ke r i in., Karaites, w: M. B e re n b a u m, F. Sk oln i k (red.), Encyclopaedia Judaica, t. 11, Detroit 2007, s. 786-789; G. K h a n, The Early Karaite Tradition of Hebrew Grammatical Thought, s. 1-2. 
w przeciwieństwie do tych, którzy poddali się żydowskiej tradycji ustnej. Pod tym względem ruch karaimski stał się swoistym ruchem „,̇ydowskiego protestantyzmu”, odrzucającego tradycję ustną na rzecz Biblii. Z tej racji Karaimi żywili też przekonanie, że skoro tylko oni trzymali się wyłącznie słowa Bożego zawartego w Biblii Hebrajskiej, to znaczy, że byli prawowierną cząstką Izraela. ${ }^{4}$ Tego rodzaju mniemanie o sobie jest również ewidentne w wyrażeniu bnej mikra (,synowie Pisma [świętego]”), które było używane przez Karaimów w celu określenia swojej tożsamości.

Dzisiaj przypuszcza się, że pierwsi Karaimi czerpali inspirację z ruchu saduceuszów. ${ }^{5}$ Jednak najbardziej znakomitą postacią związaną z odrzuceniem żydowskiej tradycji ustnej był Anan ben Dawid, mędrzec z rodu Dawida, żyjący w VIII w. Pierwsze wzmianki o nim pojawiają się w źródłach karaimskich z X w. ${ }^{6}$ Jego konflikty z władzami rabinicznymi sprawiły, że w końcu znalazł się w więzieniu. Przekonał jednak miejscowego kalifa, że ani on, ani jego zwolennicy nie mogą być uznani przez muzułmanów za Żydów ze względu na odrzucenie przez nich rabinicznej tradycji ustnej. W konsekwencji kalif uwolnił Anana ben Dawida, który następnie osiedlił się w Bagdadzie. ${ }^{7}$ Jego publiczne orzeczenie przed muzułmanami

4 Należy zauważyć, że hebrajski rdzeń kara oznacza nie tylko „czytać”, ale również ,zawołać”. Ten fakt staje się znamienny w świetle roli, którą pełni w meczecie muzułmański muezin (dosłownie: „ten, kto słucha”). Gdy bowiem muezin nawołuje do modlitwy, wówczas przykłada rękę do ucha, aby zaznaczyć, że jego nawoływanie do modlitwy wypływa z tego, co sam słyszy od Stwórcy. Tę samą konotację zawiera termin karaim („karaimi”) lub karai („karaita”) w związku z karaimskim stwierdzeniem, że lektura biblijna prowadzi karaimów do wniosków natchnionych przez Boga, zaczerpniętych bezpośrednio z czytanego i słuchanego biblijnego tekstu, a nie z tradycji ustnej. Por. D. J. L a s k e r i in., Karaites, s. 785.

5 Por. D. F r a n k, Search Scripture Well. Karaite Exegesis and the Origins of the Jewish Bible Commentary in the Islamic East, w: P. B. F e n t o n (red,), Etudes sur Le Judaisme Medieval, t. 29, Leiden 2004, s. 1.

6 Por. L. N e mo y, Anan ben David, w: M. B e re n b a u m, F. S k o $1 \mathrm{n}$ i k (red.), Encyclopaedia Judaica, t. 2, s. 127.

7 Por. tamże. 
o odrzuceniu autorytetu rabinicznego sprawiło, że wraz ze swoimi zwolennikami cieszył się łagodniejszym traktowaniem przez społeczność muzułmańską.

Ów epizod z życia Anana ben Dawida ma swoje odzwierciedlenie w dalszym ciągu ruchu Karaimów, bo na przestrzeni wieków, w wielu środowiskach, gdzie społeczność żydowska była prześladowana, Karaimi powoływali się na swoją odrębność od reszty Żydów i byli w stanie zapewnić sobie w ten sposób przychylność władz. Niewątpliwie ta taktyka przyczyniła się do ich przetrwania w wielu miejscach, gdzie inni Żydzi nie przetrwali. ${ }^{8}$

Odrzucenie tradycji ustnej na rzecz ścisłej interpretacji tekstu masoreckiego sprawiło, że Anan ben Dawid i jego następcy stali się zwolennikami pogłębienia znajomości hebrajskiej gramatyki w celu wyjaśnienia poszczególnych słów i wyrażeń w Biblii Hebrajskiej. Co prawda egzegeza rabiniczna też bazuje na obszernej znajomości hebrajskiej gramatyki, chociaż komentatorska metoda karaimska zmierza ku temu, by rozpocząć wyjaśnienie danego słowa lub wyrażenia $\mathrm{w}$ poszczególnym wersecie przez ukazanie związku z sąsiadującym słowem lub wyrażeniem. ${ }^{9}$ Pod tym względem odwołanie się do obrazów midraszowych jest rzadkie w egzegezie karaimskiej.

\section{Jefet ben Eli - przedstawiciel karaizmu średniowiecznego}

Jednym z najbardziej znakomitych przedstawicieli średniowiecznego karaizmu był Jefet ben Eli (po arabsku Abu Ali Hasan Ibn Ali Albasri). Urodzony w pierwszej połowie X w., pochodził najprawdopodobniej z miasta Basra w południowo-wschodnim Iraku w pobliżu Zatoki Perskiej. Między 950 a 980 r. przeprowadził się do Jerozolimy, gdzie zasłynął wiedzą biblijną w środowisku karaimskim. Był

\footnotetext{
8 Obecnie ortodoksyjny judaizm nie uznaje Karaimów za autentycznych Żydów.

9 M. G old s te i n, The Beginning of the Transition from „Derasz” to „Peshat”, as Exemplified in Yefet ben 'Eli's Comment on Psa. 44:24, w: G. K h a n, Exegesis and Grammar in Medieval Karaite Texts, Journal of Semitic Studies Supplement 13, Oxford 2001, s. 41.
} 
pierwszym żydowskim egzegetą, który napisał komentarz do całej Biblii Hebrajskiej. ${ }^{10}$ Poświęcił ostatnie czterdzieści lat swojego życia pracy translatorskiej i komentatorskiej. Napisał też dzieło halachiczne pod tytułem Sefer hamitswot. Cieszył się wielkim uznaniem wśród karaimskich egzegetów w średniowieczu, a jego komentarze były cytowane i pogłębiane przez żydowskich komentatorów rabinicznych, zwłaszcza dwunastowiecznego hiszpańskiego egzegetę Awrahama Ibn Ezra. ${ }^{11}$ Jefet ben Eli zmarł w Jerozolimie pod koniec X w., w czasie, kiedy ruch karaimski cieszył się największym rozkwitem pod względem duchowym i naukowym.

\section{Komentarz Jefeta ben Eliego do Księgi Ozeasza}

Cechy ogólne

Jefet ben Eli uważał, że księgi prorockie zawierają realne przesłanie dla wszystkich przyszłych pokoleń Izraela. O ile główny nurt karaimskiej egzegezy doszukiwał się w Biblii przesłania odnośnie do roli, którą Karaimi mieli pełnić w planach Bożych, o tyle Jefet doszukiwał się w tekście masoreckim przesłania nie tylko do zawężonej społeczności karaimskiej, lecz dla wszystkich Żydów. Kładąc nacisk na wymiar wychowawczy i duchowy ksiąg prorockich, Jefet jest bliski w swoim myśleniu do komentatorów rabinicznych,

10 Por. K. A $1 \mathrm{~m}$ b la d h, MS Uppsala O Nova 791 - a rediscovered manuscript of the Arabic translation of and commentary on the Song of Songs by Yapheth ben Eli, Orientalia suecana LXI Suppl. 2012, s. 33. Na temat dzieł badawczych poświęconych działaności Jefeta ben Eliego zob. M. Z a w a n o w s k a, Review of Scholarly Research on Yefet Ben Eli and His Works, Revue des Études Juives 173(2014)1-2, s. 97-138.

11 Por. M. P olli a c k, E. S c h lo s s b e r g, Historical-literary, Rhethorical and Redactional Methods of Interpretatioin in Yefet ben 'Eli's Introduction to the Minor Prophets, w: G. K a h n, Exegesis and Grammar in Medieval Karaite Texts, s. 4; M. P o 11 i a c k, The Karaite Tradition of Arabic Bible Translation. A Linguistic and Exegetical Study of Karaite Translations of the Pentateuch from the Tenth and Eleventh Centuries C.E., w: P. B. F e n t o n, E. R. Wol f s o n (red.), Etudes sur Le Judaisme Medieval, t. 17, Leiden 1997, s. 17. 
chociaż - podobnie jak inni Karaimi - dostrzega w księgach prorockich narzędzie do odgadnięcia przyszłości.

Skoro Księga Ozeasza jest pierwszym dziełem wśród dwunastu Ksiąg Proroków Mniejszych, Jefet uznał ją za dzieło wprowadzające w tematykę prorocką. Dlatego też przytacza obszerne wprowadzenie do swojego Komentarza do Księgi Ozeasza, gdzie wymienia przyczyny, dla których Bóg posyłał proroków i wskazuje na cele, które miały być osiągnięte przez czytanie ksiąg prorockich. ${ }^{12}$

Komentarz Jefeta ben Eliego do Księgi Ozeasza został napisany w języku arabskim, aczkolwiek literami hebrajskimi. Wśród arabskich słów pojawiają się też słowa ściśle hebrajskie, jak również hebrajskie słowa w dialekcie arabskim. Komentarz rozpoczyna się od następujących słów: „Niech będzie błogosławiony Bóg Izraela, jedyny, pierwotny, istniejący, wieczny bez końca, Stworzyciel, kierujący swoim światem w każdej chwili..."13

Należy zauważyć, że owe słowa uwielbienia są napisane w stylu przypominającym słowa uwielbienia w Koranie: „W imię Boga miłosiernego, litościwego. Chwała Bogu, Panu światów. Miłosiernemu, litościwemu. Królowi dnia Sądu..."14

Podobieństwo pod względem stylistycznym do Koranu nie jest przypadkowe, bo w tym samym wstępie do Księgi Ozeasza, po słowach pochwały na rzecz narodu wybranego (na podstawie Psalmu 135,4), gdy Jefet omawia przyczyny, dla których Bóg wybrał i posłał proroków, nawiązuje do postaci Mojżesza, ale nie imiennie, lecz przy

12 Zob. M. P olli a ck, E. S c hl o s s be rg (red,), Yefet ben 'Eli's Commentary on Hosea. Annonated Edition, Hebrew Translation and Introduction, Ramat Gan 2009, s. 259-261. Dzieło zredagowane przez M. Polliack i E. Schlossberg jest najnowższym krytycznym hebrajskim wydaniem Komentarza Jefeta ben Eliego do Księgi Ozeasza. Na tym dziełu bazuje niniejsze opracowanie.

13 Tamże, s. 259.

14 Al Fatihah, 1.1-4, w: H. M. Tah i r A h m a d (red.), Święty Koran. Tekst arabski i thumaczenie polskie. Translation of the Holy Quran in Polish, Tilford, U.K. 1996. 
użyciu arabskiego tytułu al rasul, czyli ,posłaniec". ${ }^{15}$ Ten termin jest znamienny, bo to samo określenie (rasul) jest użyte w Koranie w odniesieniu do Mahometa oraz do proroków. W związku z tym można powiedzieć, że Jefet wpisuje się w egzegezę karaimską, której cechą charakterystyczną jest posługiwanie się terminologią muzułmańską. Do tej terminologii dochodzą też narzędzia literackie, którymi posługiwali się muzułmańscy uczeni nie tylko w obszarze religijnym, ale również i filozoficznym. ${ }^{16}$

Użycie terminologii muzułmańskiej u Jefeta wynikało nie tylko z faktu, że Żydzi na ziemiach Mezopotamii mieli stałą styczność z Arabami. Zwłaszcza w przypadku Jefeta, który cały swój Komentarz do Biblii Hebrajskiej sporządził w języku arabskim, używanie muzułmańskiej terminologii mogło wynikać ze świadomości, że dzieła jego autorstwa będą czytane nie tylko przez Żydów, ale również - z ciekawości - przez muzułmanów. Inaczej mówiąc, jest bardzo możliwe, że w osobie Jefeta ben Eliego mamy do czynienia z karaimskim egzegetą, który kierował się zamysłem apologetycznym. ${ }^{17}$

Po słowach wstępu Jefet przechodzi do komentowania każdego wersetu po kolei. Czyni to według stałego schematu, mianowicie najpierw podaje własny arabski przekład z tekstu masoreckiego, następnie przystępuje do komentowania. Przekład arabski Jefeta jest podany bezpośrednio bez hebrajskiej wersji masoreckiej. Dopiero w arabskim komentarzu Jefet odnosi się do poszczególnych hebrajskich słów i wyrazów z tekstu masoreckiego, nie omijając żadnego. Tam, gdzie uważa to za stosowne, wyjaśnia też wątki gramatyczne.

Na końcu Komentarza do Księgi Ozeasza Jefet przytacza listę trudnych hebrajskich słów w tekście masoreckim i podaje ich morfologię, nawiązując do różnych miejsc w Biblii Hebrajskiej, gdzie te słowa się pojawiają. Co prawda ta lista nie jest wyczerpująca i nie zawiera nowej informacji, której nie ma w samym Komentarzu. Jest

15 M. P olli a c k, E. S c h l o s s b e rg, Yefet ben 'Eli's Commentary on Hosea, s. 259.

16 Por. D. F r a n k, Search Scripture Well, s. 257.

17 Por. M. P o 11 i a c k, The Karaite Tradition of Arabic Bible Translation, s. 3. 
ona jedynie swoistym streszczeniem dzieła Jefeta, które umożliwia czytelnikowi szybki wgląd w wybrane zagadnienia i sprawdzenie ogólnych informacji z przekładu oraz Komentarza.

Wybrane zagadnienia z Komentarza

Analiza nazw i określeń (Oz 1,2-3)

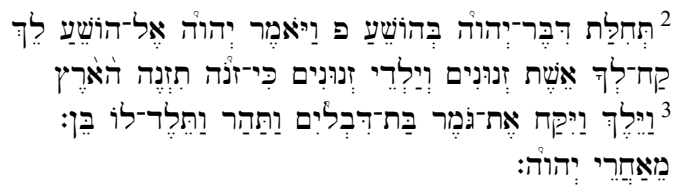

„Początek mowy Pana do Ozeasza. I powiedział Pan Ozeaszowi: Idź, weź sobie za żonę nierządnicę [eszet znunim] i dzieci z nierządu [jaldej znunim], bo ziemia dokonała nierządu, oddalając się od Pana. I poszedł i wziął Gomer-bat-Diwlaim. I poczęła i urodziła mu syna".

Przekład Jefeta z języka hebrajskiego na język arabski wygląda następująco:

„Pierwsza mowa Boga do Ozeasza, powiedział do niego [Bóg]: Idź, weź za żonę bałwochwalczynię i urodzi ci dzieci, które są bałwochwalcami, bo przecież ziemia odejdzie od kultu Bożego". I poszedł i poślubił żonę, której na imię było całość, córkę dwóch połówek, a ona stała się brzemienna i urodziła mu syna".

I. Przekład Eszet znunim dostosowany do czytelnika oraz interpretacja alegoryczna na podstawie zbędnych słów ki zano tizne haarets maacharej adonaj $(\mathrm{Oz} 1,2)$.

Biorąc pod uwagę akcent, który egzegeza karaimska kładzie na dosłowną wierność tekstom masoreckim, powyższy przekład Jefeta na język arabski może wzbudzić dziwienie. Jefet bowiem nie podaje dosłownego tłumaczenia z języka hebrajskiego, lecz uwzględnia swoją interpretację w samym przekładzie, jeszcze zanim przystępuje 
do komentowania powyższych wersetów. Dopiero w komentarzu Jefet podaje dosłowny przekład słów tekstu masoreckiego i pisze, że opis odnosi się do nierządnicy oraz do dzieci nierządu. Dlaczego więc pojawia się rozbieżność między nieścisłym przekładem Jefeta $\mathrm{z}$ tekstu masoreckiego, a treścią komentarza do tego tekstu? Tu właśnie widnieje potwierdzenie hipotezy, że Jefet uważał, iż muzułmanie będą czytać jego przekład z masoreckiego tekstu Księgi Ozeasza na język arabski. Wiedząc, jak wielkie znaczenie ma urząd proroka dla muzułmanów, Jefet nie chciał, by już na początku muzułmański czytelnik był zgorszony nakazem Bożym skierowanym do proroka, aby poślubił prostytutkę. Dopiero w komentarzu do przełożonych przez niego wersetów z języka arabskiego Jefet nawiązuje po raz pierwszy do dosłownego znaczenia hebrajskiego określenia eszet znunim (,nierządnica”) oraz jaldej znunim (,dzieci nierządu”).

Jefet sugeruje, że gdy Pan Bóg zwrócił się do Ozeasza i kazał mu poślubić nierządnicę, nakaz Boży nie odnosił je do fizycznej kobiety, lecz do narodu Izraela.W celu uzasadnienia tej interpretacji, Jefet zaznacza, że werset drugi kończy się słowami, których normalnie nie powinno tam być: „Weź sobie nierządnicę i dzieci nierządu, bo uprawiając nierząd, ziemia będzie uprawiać nierząd, odwracając się od Pana”. Jefet pisze, że określenie „odwracając się od Pana" jest zbędne i nie znalazłoby się tutaj, gdyby rzeczywiście chodziło o zawarcie realnego małżeństwa z nierządnicą, nawet jeżeli ta nierządnica miałaby jednocześnie symbolizować naród Izraela. Wobec tego - mówi Jefet - skoro pojawiły się w tym miejscu słowa „odwracając się od Pana”, to znaczy że nakaz nie dotyczył zawarcia małżeństwa lecz sytuacji, w której znalazł się Ozeasz jako prorok obserwujący żałosny stan moralny swojego narodu.

II. Interpretacja imienia Gomer bat diwlaim w odniesieniu do stanu narodu i do pokrewnych słów $(\mathrm{Oz} 1,3)$.

Komentując imię Gomer bat diwlaim, Jefet zaczyna od słowa Gomer. Powołuje się na źródłosłów gamar, który odnosi się do zakończenia lub pełni czegoś. W związku z tym - według Jefeta - imię Gomer może oznaczać „,pełnię”, czyli maksymalną liczbę przekroczeń 
moralnych narodu Izraela ze względu na odejście od prawidłowego kultu Bożego i Bożych nakazów. Oznacza to, że pod względem moralnym naród Izraela znalazł się na samym dnie. Idąc dalej, przy analizie terminu diwlaim Jefet jest świadomy problemu, że to słowo nie znajduje się nigdzie w Biblii Hebrajskiej. Proponuje możliwą interpretację tego słowa przez ukazanie jego związku z terminem $d$ wela, jak w 1Sm 30,12, gdzie pojawia się wyrażenie pelach dwela, czyli „kawałek placka figowego”, albo podobnie jak w $2 \mathrm{Krl} 20,7$, gdzie znajduje się wyrażenie dwelet teenim, czyli ,placek figowy”. Na tej podstawie, pisze Jefet, można wnioskować, że bat diwlaim to po prostu córka ,dwóch połówek”. Jak to zrozumieć? Jefet proponuje, że owe dwie połówki placka figowego odnoszą się obrazowo do Mojżesza i Aarona, którzy pochodzili z jednego ojca i z jednej matki. To właśnie Mojżesz i Aaron - dodaje Jefet - byli dla Izraela ojcem i matką, bo sam Mojżesz zapytał: „Czy to ja począłem ten lud w łonie?" (Lb 11,12).

III. Interpretacja nazwy Jizreel na podstawie nowatorskiej analizy etymologicznej $(\mathrm{Oz} 1,4)$.

Nawiązując do poczęcia pierwszego syna - Jizreela - przez Gomer (Oz 1,4), Jefet tłumaczy, że interpretacja tej informacji musi być metaforyczna. W związku z tym Jizreel - w mniemaniu Jefeta - reprezentuje każde pokolenie aż do Jehu ben Nimszi, ${ }^{18}$ wywodzące się z króla Jeroboama II i j ego podwładnych, wychowanych na bałwochwalstwie. Znamienny jest jednak sposób interpretowania imienia Jizreel przez Jefeta. Tradycja rabiniczna postrzega tutaj dwa słowa, mianowicie czasownik zara, czyli ,siać”, oraz słowo el, czyli „Bóg”, a razem - „Bóg będzie siał” - izra el, co w formie imiennej brzmi Jizreel. ${ }^{19}$ Jefet przyjmuje, że w imieniu Jizreel jest zawarty rdzeń zara - „siać”, natomiast nie dostrzega w ostatnich dwóch literach

18 Ten król był odpowiedzialny za zniszczenie domu Achaba oraz stracenie proroków Baala.

19 Zob. Y. K i e 1, Sefer Hoshea, w: A. Mirs k i i in. (red.), Trey Asar, t. 2: Daat Mikra, Jerusalem 1990, s. 4-5. 
imienia Jizreel (alef i lamed) odniesienia do Boga (el) lecz do negującego słowa al. Interpretacja Jefeta nie jest bez uzasadnienia, bo w tekście masoreckim dwie ostatnie litery imienia Jizreel (alef i lamed) - są bez znaków masoreckich. W takim razie można przyjąć, że tu chodzi nie tyle o Pana Boga (el), który będzie siał (izra), lecz raczej o zanegowanie akcji siania (al izra). Jest to więc odwrotny wniosek niż ten, do którego dochodzi interpretacja rabiniczna. Brak siania oznacza w ten sposób brak Bożego błogosławieństwa dla potomków Jeroboama oraz dla tych, którzy wśród Izraelitów pójdą za pogaństwem.

Od symboliki do postawy moralnej $(\mathrm{Oz} 1,6)$

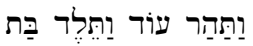

„I poczęła znowu [jeszcze] i urodziła córkę".

Jefet tłumaczy, że o ile symboliczni synowie zrodzeni z symboe licznej nierządnicy Gomer oznaczają silnych potomków - aczkolwiek niewiernych Bogu - o tyle symboliczne córki zrodzone z symbolicznej Gomer oznaczają słabych potomków. W ten sposób płeć dziecka staje się alegorią silnej i stałej właściwej postawy moralnej.

Rozwiązanie teologiczne za cenę odejście od literalnej interpretacji $(\mathrm{Oz}$ 1,7)

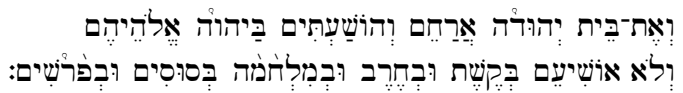

„Nad domem Judy zlituję się i wybawię ich w Panu ich Bogu i nie wybawię ich za pomocą łuku i miecza ani wojny, koni czy jeźdźców”. 
Arabski przekład Jefeta brzmi następująco: „Zlituję się nad domem Judy i wybawię ich w imieniu Pana ich Boga i nie wybawię ich za pomocą łuku i miecza ani sprzęty wojny, koni czy jeźdźców”.

Z powyższego przekładu na język arabski wynika, że Jefet podejmuje osobliwy manewr egzegetyczny. Bowiem w tekście masoreckim znajdują się słowa wypowiedziane przez Boga, których dosłowne

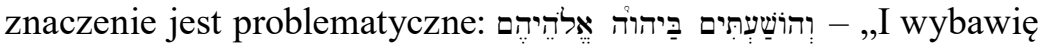
ich w Panu ich Bogu". Problem polega na tym, że skoro Bóg mówi o sobie, iż wybawi Izraelitów za przyczyną Pana ich Boga, to odnosi się wrażenie, że jest dwóch Bogów: pierwszy Bóg, to ten, który kieruje te słowa do Ozeasza (,Nad domem Judy zlituję się i wybawię ich"), a druga osoba, to ta, którą Bóg się posłuży w celu wybawienia narodu (,w Panu ich Bogu”) i którą sam Bóg określa mianem „Pana” i „Boga”. Takie jest literalne znaczenie tych wyrazów, wskazujących jednocześnie na dwie Osoby Boskie. Jefet jako Karaita musiał to zauważyć, bo zgodnie z karaimską tradycją egzegetyczną należy zwrócić uwagę przede wszystkim na dosłowne znaczenie tekstu masoreckiego. W związku z tym, jako Żyd nieuznający tajemnicy Trójjedynego Boga, Jefet dochodzi do jedynego możliwego wniosku (z punktu widzenia żydowskiego), że interpretacja tutaj nie może być dosłowna. $Z$ tej racji, przekładając ten werset, dodaje arabski wyraz bism, czyli „w imię", co prowadzi do następującego przekładu: „Wybawię ich w imieniu [bism] Pana ich Boga”. Oznacza to, że Bóg wybawi swój lud za przyczyną swojego imienia, tak jak wypowiadają je synowie Izraela.

Interpretacja na podstawie wątków historycznych $(\mathrm{Oz} 2,2)$

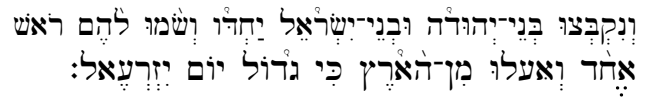

„I zgromadzą się synowie Judy i synowie Izraela razem i ustanowią sobie jedną głowę i udadzą się z kraju, bo wielki jest dzień Jizreela. 
Jefet zwraca uwagę na szczegóły, które same w sobie nie są problematyczne, chociaż w jego mniemaniu każdy szczegół - nawet najmniejszy - ma wymowne znaczenie. Widnieje to w powyższym fragmencie $(\mathrm{Oz} 2,2)$, który Jefet przekłada na język arabski w następujący sposób: „Synowie Izraela i synowie Judy zgromadzą się razem i ustanowię sobie jednego przewodniczącego i udadzą się z kraju zanim dzień wybawienia Jizreela będzie wielki.

Wymownym elementem tutaj jest zmiana kolejności dokonana przez Jefeta, gdy pisze o synach Izraela i synach Judy. Tekst masorecki podaje najpierw synów Judy, a później synów Izraela. Jefet, w przekładzie na język arabski, odwraca kolejność, nie podając przyczyny. Podaje jednak inną osobliwą myśl, gdy zaznacza, że kiedykolwiek nazwy Israel (Izrael) oraz Jehuda (Juda) występują razem, wówczas Izrael jest pierwszy pod względem chronologicznym ze względu na fakt, iż jako pierwszy został wygnany (przez Asyryjczyków), natomiast Juda jest pierwszy pod względem cierpienia, bo to właśnie potomkowie Judy wycierpieli najwięcej z racji zburzenia pierwszej i drugiej świątyni jerozolimskiej. W tych słowach Jefet nieświadomie - odnosi się do Mesjasza wywodzącego się nie tyko z rodu Dawida, ale i z pokolenia Judy. Zburzenie pierwszej i drugiej świątyni staje się dalekim odniesieniem do męki Pana Jezusa.

Jefet podaje też kilka możliwości, co do tożsamości ,głowy” wspomnianej w Oz 2,2. Na pierwszym miejscu wymienia Eliasza, ${ }^{20}$ na drugim nieokreślonego mędrca w ogólnym sensie, a na trzecim miejscu Mesjasza, który zjednoczy wszystkie pokolenia Izraela i Judy.

\section{Interpretacja czasownika כרה na podstawie nowatorskiego spostrzeżenia etymologicznego $(\mathrm{Oz} 3,2)$

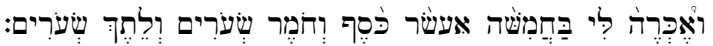

W tym miejscu warto przytoczyć przekład Biblii Tysiąclecia: „Nabyłem ją za piętnaście syklów srebrnych i za półtora korca jęczmienia”.

20 Jefet podaje, że sugestia, iż chodzi o Eliasza, pochodzi od tradycji rabinicznej. Określa komentatorów rabinicznych mianem chachamim (,mędrcy”). 
Trudność egzegetyczną w powyższym fragmencie stanowi pierwsze słowo - waekreha - które występuje w tekście masoreckim w tej formie tylko w tym miejscu. Tradycja rabiniczna dostrzega w terminie waekreha czasownik כרה - kara, czyli „nabyć” (,Nabyłem ją za piętnaście syklów srebrnych, za półtora korca jęczmienia”). ${ }^{21}$ Jefet zaś dostrzega tutaj czasownik נכר - nachar jak w rzeczowniku הכרה - hakara (,poznanie”). Dlatego też tłumacząc ten werset na język arabski Jefet podaje: „Sprawię, że będzie poznana przez innych jako moja, za piętnaście syklów srebrnych..." Wobec tego - według Jefeta - nie chodzi o to, że prorok nabył nierządnicę za podaną sumę. Chodzi raczej o to, że dając ludziom pieniądze prorok sprawił - symbolicznie - iż zgodzili się uznać, że ta kobieta jest teraz jego żoną. Taka interpretacja idzie w parze z przekonaniem Jefeta, że prorok nie pisze o swojej żonie, lecz raczej o narodzie Izraela.

Uwzględnienie wiedzy potencjalnego arabskiego czytelnika w przekładzie $(\mathrm{Oz} 3,4)$

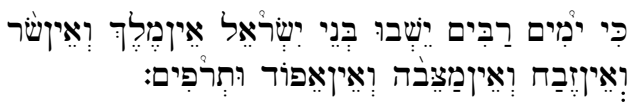

„Bo wiele dni bowiem synowie Izraela będą bez króla i bez zwierzchnika, bez ofiary i bez pomnika, bez efodu i trafim".

Jefet tłumaczy powyższy fragment na język arabski w następujący sposób: „Przez długi czas synowie Izraela pozostaną bez króla, bez zwierzchnika, bez ofiary, bez pomnika, bez efodu o bez astrolabium [astralab]".

Użycie w tym miejscu arabskiego słowa astralab (,astrolabium”) jest znamienne, bo wśród Żydów termin trafim był powszechnie znany jako jeden z elementów stroju kapłańskiego używany przez kapłana do wróżenia. $Z$ tej racji Jefet nie musiał przekładać tego terminu na

${ }^{21}$ Zob. M. P olli a c k, E. S c h 1 o s s be rg, Yefet ben 'Eli's Commentary on Hosea, s. 294, przyp. 2. 
język arabski, lecz mógł go pozostawić w hebrajskim oryginale, jak to zresztą czyni w innych przypadkach. ${ }^{22}$ Skoro jednak postanowił użyć arabskiego słowa astralab do określenia terminu trafim, można przypuszczać, że widnieje tu kolejny dowód, iż Karaita pragnął być nie tylko zrozumiany przez Żydów, ale również przemówić do muzułmańskich Arabów czytających jego przekład oraz interpretację. Co prawda astrolabium nie wyraża dosłownie tego, co oznacza hebrajskie słowo trafim, natomiast Arabowie wiedzieli, czym jest astrolabium, bo arabscy astrolodzy i astronomowie posługiwali się tym sprzętem do przewidzenia pozycji słońca, księżyca oraz gwiazd.

\section{Zapowiedź przyszłości dla Izraela (Oz 6,2)}

Bardziej niż inni karaimscy komentatorzy Jefet w swojej egzegezie posługuje się obrazami wziętymi z życia, które przypominają metodę rabiniczną w celu objaśnienia i przybliżenia realiów ujętych w poszczególnych wersetach. Wymownym przykładem pod tym względem jest jego komentarz do Oz 6,2:

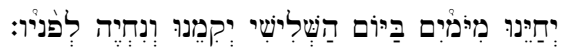

„Ożywi nas po dwóch dniach, trzeciego dnia podniesie nas i będziemy żyć w jego obliczu".

Arabski przekład Jefeta brzmi następująco: „Uzdrowi nas po dwóch dniach, trzeciego dnia podniesie nas i będziemy żyć w jego obliczu".

Jefet uzasadnia przekład pierwszego słowa jechajenu na ,uzdrowi nas" na podstawie Iz 38,9, gdzie czasownik chaja (חיה) oznacza

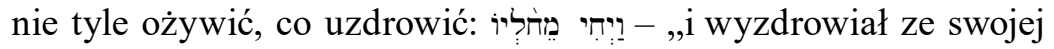
choroby". Wymowny natomiast jest ciąg dalszy komentarza, gdy Jefet dokonuje zestawienia z działaniem uczonego lekarza, który

22 Przykładem jest słowo goim, który występuje w języku arabskim bez przekładu; zob. tamże, s. 172. 
w pierwszy dzień spotkania pacjenta poświęca czas na obserwację, aby zapoznać się z symptomami choroby. Dopiero drugiego dnia podaje mu leki, a w rezultacie choroba opuszcza pacjenta, tak że powstaje dnia trzeciego i zostaje uzdrowiony. Jefet wówczas dodaje, że w podobny sposób Bóg sprowadził na Izraela różne choroby, aż poganie stwierdzili, że ten naród już nie wyzdrowieje. Jednak Pan wszechświata, który policzkował swój naród za przyczyną chorób będzie też tym, który uzdrowi Izraela o wiele szybciej gdy spojrzy na nich w chwili ich nawrócenia. O ile Jefet, podobnie jak komentatorzy rabiniczni, zaznacza w tym miejscu, że ów werset odnosi się do powrotu Żydów z wygnania, o tyle tylko Jefet dostrzega w wyrażeniu lefanaw - „w Jego obliczu / w Jego obecności” bezpośrednie odniesienie do Ziemi Izraela. Pod tym względem Jefet, który spędził drugą połowę swojego życia w Jerozolimie, potwierdza przekonanie żydowskie, że ziemia Izraela cieszy się szczególną Bożą łaską. Podobnie jak prorok Jonasz, który mówi o swoim wygnaniu i o niemożliwości ujrzenia świątyni w kategoriach bycia poza zasięgiem Bożego spojrzenia (Jon 2,5), Jefet uznaje, że ,bycie przed obliczem Boga", to przywilej, którym cieszy się osoba mieszkająca na terenie Ziemi Obiecanej.

Krótki przegląd wybranych zagadnień z Komentarza Jefeta ben Eliego do Księgi Ozeasza pokazuje nam, że punkt wyjścia karaizmu, podobnie jak punkt wyjścia protestantyzmu, dość szybko legł w gruzach. Nie można czytać Pisma Świętego bez interpretacji, jak również bez tradycji interpretacyjnej, od której Karaimi nie mogli się uwolnić. Sam Jefet ben Eli utworzył własną tradycję egzegetyczną, z której korzystali inni Karaimi tworzący na przestrzeni wieków własne komentarze. Mimo polemiki między nurtem karaimskim a rabinicznym Karaimi korzystali z tradycji rabinicznej, chociaż najczęściej się do tego nie przyznawali. Znamienny jest wymiar apologetyczny Komentarza Jefeta. Chęć dotarcia do muzułmanów za przyczyną swojego dzieła jest unikalna wśród egzegetów karaimskich i świadczy 
o przekonaniu Jefeta, że „misyjny” charakter ruchu karaimskiego należało realizować w sposób praktyczny i dostępny - przynajmniej pod względem językowym.

Obserwacje, interpretacje oraz dogłębna znajomość języka hee brajskiego u Jefeta ben Eli są tak obszerne, że pozwoliły mu na nowatorskie etymologiczne wnioski w odniesieniu do imion, nazw, czasowników oraz symboliki biblijnej. Tego rodzaju umiejętność i osiągnięcia Jefeta zasługują na dalsze badania. Skoro interpretacja rabiniczna jest cenna, wiadomo, jak cenna jest też egzegeza rabiniczna w analizie tekstu hebrajskiego Starego Testamentu, rozszerzenie zainteresowania tą interpretacją o egzegezę karaimską niewątpliwie przyczyni się do dalszych refleksji na temat biblijnego tekstu.

\section{ks. Jacek STEFAŃSKI}

Słowa kluczowe: Karaizm, Karaimi, tekst masorecki, język hebrajski, apologetyka, interpretacja literalna, tradycja ustna, egzegeza rabiniczna Keywords: Karaism, Karaite Judaism, Masoretic Text, Hebrew, apologetics, literal interpretation, oral tradition, rabbinic exegesis

\section{Middle Age Karaite Exegesis as Evidenced in Selected Examples from Yefet ben Eli's Commentary to the Book of Hosea}

\section{Summary}

For many years, Karaite exegesis had been relatively unknown to numerous Biblical scholars. This situation has been changing with an increasing access to source materials. As a result, more and more Karaite exegetical treasures representing the trends of Karaite Judaism have come to the fore. One of them is the Commentary to the Book of Hosea by Yefet ben Eli, one of Karaism's tenth century most significant representatives. Yefet ben Eli exhibits a remarkable knowledge of Hebrew etymology which enables him to provide unique answers to interpretative problems in the Masoretic Text. His apologetic concern for prospective Muslim readers of his commentary 
is also noteworthy. Although, in general, Karaism sought to concentrate on the literal sense of Scripture, Yefet ben Eli does not shy away from recourse to rabbinic oral tradition. Still, his exegetical contribution remains unique, as selected examples from his Commentary clearly show. 